\title{
Proposal of Lysinibacillus boronitolerans gen. nov. sp. nov., and transfer of Bacillus fusiformis to Lysinibacillus fusiformis comb. nov. and Bacillus sphaericus to Lysinibacillus sphaericus comb. nov.
}

\author{
Correspondence \\ Iftikhar Ahmed \\ iftikharnarc@hotmail.com \\ Toru Fujiwara \\ atorufu@mail.ecc.u-tokyo.ac.jp
}

\author{
Iftikhar Ahmed, ${ }^{1,2}$ Akira Yokota, ${ }^{3}$ Atsushi Yamazoe $^{4}$ and Toru Fujiwara ${ }^{1,5}$ \\ 'Biotechnology Research Center, University of Tokyo, Yayoi 1-1-1, Bunkyo-ku, \\ Tokyo 113-8657, Japan \\ ${ }^{2}$ National Agricultural Research Centre, Park Road, Islamabad - 45500, Pakistan \\ ${ }^{3}$ Institute of Molecular and Cellular Biosciences, University of Tokyo, Yayoi 1-1-1, Bunkyo-ku, \\ Tokyo 113-8657, Japan \\ ${ }^{4}$ Research Center for Water Environmental Technology, University of Tokyo, Hongo 7-3-1, \\ Bunkyo-ku, Tokyo 113-8657, Japan \\ ${ }^{5}$ SORST, JST, Chiyoda-ku, Tokyo, Japan
}

Boron is an essential micronutrient for plants (Warington, 1923) and possibly also for animals (Rowe et al., 1998; Rowe \& Eckhert, 1999). In bacteria, Chen et al. (2002) presented evidence for the biological role of boron in quorum sensing. On the other hand, boron is toxic to living cells when present above a certain threshold. Because of its toxic effects at high

The GenBank/EMBL/DDBJ accession numbers for the 16S rRNA gene sequences of strains $10 \mathrm{a}^{\top}, 11 \mathrm{c}$ and $12 \mathrm{~B}$ are respectively AB199591-AB199593.

Results of growth experiments in the presence of boron, photomicrographs of cells of strain $10 \mathrm{a}^{\top}$ and results of separation of polar lipids of strain $10 \mathrm{a}^{\top}$ and related type strains are available as supplementary material in IJSEM Online. concentrations for micro-organisms, boron has been used as a food preservative (Nielsen, 2004), and it has also been used as an insecticide against cockroaches (Cochran, 1995). However, only recently, Bacillus boroniphilus, Chimaereicella boritolerans and Gracilibacillus boraciitolerans have been reported to tolerate more than 450,300 and $450 \mathrm{mM}$ boron, respectively, and/or require boron for growth (Ahmed et al., 2007a, b, c).

Over the last decade, the genus Bacillus has been dissected taxonomically into several new genera based on comprehensive analyses of 16S rRNA gene sequences and other chemotaxonomic data (Wisotzkey et al., 1992; Ash et al., 1993; Shida et al., 1996; Heyndrickx et al., 1998; Wainø et al., 
1999; Yoon et al., 2001, 2002). rRNA group 2 of the genus Bacillus (Ash et al., 1991) containing L-lysine or D-ornithine in the peptide subunit also includes non-Bacillus-type organisms such as members of Caryophanon, Kurthia, Sporosarcina, Planococcus and Filibacter (Clausen et al., 1985; Keddie \& Shaw, 1986; Stackebrandt et al., 1987; Pechman et al., 1976; Farrow et al., 1994). There is a need to re-evaluate the taxonomic status of this group. Although it has been discussed previously (Farrow et al., 1994; Rheims et al., 1999), no proposal has yet been put forward to transfer these organisms into one or more new or existing genera. In this paper, we characterize three round-spore-forming strains belonging to a new genus in Bacillus RNA group 2 . This genus is distinguished from other members of this group by the presence of lysine and aspartate in the peptidoglycan of the cell wall.

The three strains were isolated from soil sampled randomly from the experimental field of the University of Tokyo (Yayoi campus), Japan. We used previously described isolation and enrichment procedures (Ahmed et al., 2007a). The purified isolates (strains $10 \mathrm{a}^{\mathrm{T}}, 11 \mathrm{c}$ and $12 \mathrm{~B}$ ) were maintained on agar medium, and also stored as glycerol (35\%, $\mathrm{w} / \mathrm{v}$ ) stocks at $-80^{\circ} \mathrm{C}$, and subjected to characterization.

To demonstrate boron tolerance, strain $10 \mathrm{a}^{\mathrm{T}}$ and Escherichia coli DH10B (control) were grown up to upper midexponential phase $\left(\mathrm{OD}_{600} 1.2\right)$ at $37^{\circ} \mathrm{C}$, with vigorous shaking. The cultures were serially diluted and $7 \mu$ aliquots were spotted onto nutrient agar medium (NA; Difco) ( $\mathrm{pH}$ 7.0) containing different levels of boron. The plates were incubated at $37^{\circ} \mathrm{C}$ for 2 days before being photographed. Strain $10 \mathrm{a}^{\mathrm{T}}$ manifested tolerance of boron up to $100 \mathrm{mM}$ on NA, whereas weak growth was observed at $150 \mathrm{mM}$ boron (Supplementary Fig. S1 in IJSEM Online). The strain was also cultured in $150 \mathrm{ml}$ Luria-Bertani (LB) medium ( $\mathrm{pH}$ 7.0) with different levels of boron ranging from 0 (control) to $300 \mathrm{mM}$, while being shaken vigorously at $30^{\circ} \mathrm{C}$. After every $60 \mathrm{~min}$, samples were taken aseptically to measure $\mathrm{OD}_{600}$ using a spectrophotometer (Hitachi $\mathrm{U}-1800)$. The data for $\mathrm{OD}_{600}$ against time plotted at different boron concentrations demonstrated that strain $10 \mathrm{a}^{\mathrm{T}}$ could grow with $0-100 \mathrm{mM}$ boron in liquid culture (LB medium) and that growth was equivalent to that without addition of boron (Supplementary Fig. S2), indicating that boron was not required for growth. However, there was no growth at $200 \mathrm{mM}$ boron and weak growth was observed at $150 \mathrm{mM}$ boron.

Sporangia and the sizes of cells grown on NA with $\mathrm{MgSO}_{4} .7 \mathrm{H}_{2} \mathrm{O} \quad(1.01 \mathrm{mM}), \quad \mathrm{KCl} \quad(13.4 \mathrm{mM}), \quad \mathrm{FeSO}_{4}$ (0.001 mM), $\mathrm{Ca}\left(\mathrm{NO}_{3}\right)_{2}(1.0 \mathrm{mM})$ and $\mathrm{MnCl}_{2}(0.01 \mathrm{mM})$ at pH 7.0 for 6 days at $30^{\circ} \mathrm{C}$ were examined under phasecontrast microscopy. Cells of the strains produced oval or spherical endospores in a terminal position in a swollen sporangium (Supplementary Fig. S3). Cells of the strains were Gram-positive as determined according to Hucker's modified method (Cowan, 1974). Colonial morphology was observed on isolated colonies grown on nutrient agar
(pH 7.0, Difco) for 2 days at $30^{\circ} \mathrm{C}$. The $\mathrm{pH}$ range for growth was determined in tryptic soya broth (TSB; Difco) with a $\mathrm{pH}$ range of 4.0 to 10.0 at $30^{\circ} \mathrm{C}$ by monitoring $\mathrm{OD}_{600}$ using a mini-photometer (model 518R; TAITEC) and the temperature range for growth was determined on tryptic soya agar (TSA; Difco) ( $\mathrm{pH}$ 7.0) by incubating at different temperatures from 4 to $50^{\circ} \mathrm{C}$. The isolated strains grew at $\mathrm{pH}$ 5.59.5 with optimum growth at $\mathrm{pH} 7.5$ and no growth at $\mathrm{pH}$ 5.0. We observed growth of the strains at $16-45^{\circ} \mathrm{C}$ with optimum growth at $37^{\circ} \mathrm{C}$; there was no growth at $\geqslant 50{ }^{\circ} \mathrm{C}$ and only slight growth after several days at $16^{\circ} \mathrm{C}$. These findings distinguished the strains from the closely related species Bacillus fusiformis and Bacillus sphaericus, which can only grow up to $40^{\circ} \mathrm{C}$. Growth at various $\mathrm{NaCl}$ concentrations was investigated on TSA $(\mathrm{pH} 7.0)$ at $30^{\circ} \mathrm{C}$. The novel strains tolerated $0-5 \%(\mathrm{w} / \mathrm{v}) \mathrm{NaCl}$ in the agar medium. This differed from B. fusiformis, which can tolerate up to $7 \%$ (w/v) $\mathrm{NaCl}$ (Priest et al., 1988). We also observed growth of the novel strains on marine agar 2216 (Difco), TSA and NA with and without addition of boron or $\mathrm{NaCl}$.

Physiological and biochemical characteristics were determined using API 20E and API 50CH galleries (bioMérieux). The strains were positive for oxidase and catalase activities as assessed by previously described procedures (Ahmed et al., 2007a). Motility was also confirmed with M medium (bioMérieux) in addition to microscopy. Since mainly negative reactions were obtained with API $50 \mathrm{CH}$ and API $20 \mathrm{E}$ for utilization of various carbon sources, we analysed an extended array of metabolic features of the strains using the Biolog GP2 and GN2 characterization system. Resistance to antibiotics was assessed with an ATB-VET strip (bioMérieux) and enzyme activities were determined with an API ZYM strip (bioMérieux). All commercial kits were used according to the manufacturers' protocols. The isolated strains exhibited many features that were similar to those of B. fusiformis and B. sphaericus; however, they differed from these species in certain physiological and biochemical characteristics (Table 1). All three novel strains gave identical results in these tests.

Nearly complete $16 \mathrm{~S}$ rRNA gene sequences of the strains were amplified by the PCR as described by Katsivela et al. (1999). The purified PCR product was sequenced as described previously (Ahmed et al., 2007a). The DNASIS Pro (Hitachi Software Engineering) software package was used to obtain the consensus sequence. Sequences of closely related type strains used for constructing the phylogenetic tree were selected and retrieved from the DDBJ/EMBL databases by BLAST searches for bacteria. Alignment was performed with CLUSTAL X (version 1.8w; Thompson et al., 1997 ) and evolutionary distances and $K_{\text {nuc }}$ values (Kimura, 1980) were generated. BioEdit software (Hall, 1999) was used to remove gaps and ambiguous bases in the alignments. A phylogenetic tree was constructed from 1294 unambiguously aligned nucleotides using the neighbour-joining method (Saitou \& Nei, 1987) contained in the PHYLIP software package (Felsenstein, 2005) and plotted with NJPlot 
software. The stability of the relationship was assessed by bootstrap analysis (Felsenstein, 2005) by performing 1000 resamplings for the tree topology of the neighbour-joining data.

An almost-complete 16S rRNA gene sequence (1484 nucleotides) of strain $10 \mathrm{a}^{\mathrm{T}}$ was compared with sequences of closely related type strains retrieved from the public DDBJ database. Based on 16S rRNA gene sequence data, the similarity of the novel strain $10 \mathrm{a}^{\mathrm{T}}$ was $97.2 \%$ to B. fusiformis DSM $2898^{\mathrm{T}}$ (GenBank accession no. AJ310083), 96.9\% to B. sphaericus DSM $28^{\mathrm{T}}$ (AJ310084), $96.1 \%$ to Bacillus odysseyi $34 \mathrm{hs}-\mathrm{1}^{\mathrm{T}}$, $95.0 \%$ to Bacillus massiliensis $4400831^{\mathrm{T}}$ and $94.5 \%$ to Bacillus silvestris HR3-23 ${ }^{\mathrm{T}}$; the similarity was $99.3 \%$ with strain $11 \mathrm{c}$ and $99.2 \%$ with strain $12 \mathrm{~B}$ after alignment, whereas strains $11 \mathrm{c}$ and $12 \mathrm{~B}$ had $99.8 \%$ similarity. The $16 \mathrm{~S}$ rRNA gene sequence of strain $11 \mathrm{c}$ was omitted during construction of the phylogenetic tree because the sequence was incomplete. The novel strains occupied a separate lineage in the phylogenetic tree with high bootstrap support (Fig. 1). Strain $10 \mathrm{a}^{\mathrm{T}}$ is closely related to $B$. fusiformis and $B$. sphaericus in many other characteristics, although the data presented here also exhibited differences from these and other type strains of the genus Bacillus (Table 1) and among closely related genera (Table 2). On the basis of morphological, physiological, phylogenetic, chemotaxonomic and genomic characteristics which we determined, strains $10 \mathrm{a}^{\mathrm{T}}$, $11 \mathrm{c}$ and $12 \mathrm{~B}$ are considered to be members of the same species.

For DNA-DNA hybridization, DNA from the isolated strains and closely related type strains was isolated using a previously described procedure (Ahmed et al., 2007a). DNA-DNA hybridization was performed at $42{ }^{\circ} \mathrm{C}$ with photobiotin-labelled DNA and microplates as described by Ezaki et al. (1989), using an HTS7000 Bio Assay Reader (Applied Biosystems) for fluorescence measurements. The DNA-DNA hybridization values among strains $10 \mathrm{a}^{\mathrm{T}}, 11 \mathrm{c}$ and $12 \mathrm{~B}$ were more than $97.8 \%$, confirming that these strains belong to the same species. However, DNA-DNA relatedness of strain $10 \mathrm{a}^{\mathrm{T}}$ was $61.1 \%$ with $B$. fusiformis DSM $2898^{\mathrm{T}}, 43.2 \%$ with B. sphaericus IAM $13420^{\mathrm{T}}$ and $26.4 \%$ with $B$. silvestris DSM $12223^{\mathrm{T}}$. These values are less than the $70 \%$ threshold needed to assign the strains to a novel species (Stackebrandt \& Goebel, 1994). The DNA G + C content of the novel strains was $36.5-37.9 \mathrm{~mol} \%$ as determined by HPLC using a procedure described previously (Ahmed et al., 2007a).

Respiratory quinones were analysed as described by Xie \& Yokota (2003) and MK-7 (87\%) was determined as the predominant quinone system in the novel strains, although MK-6 (13\%) was also detected as a minor component. The purified cell wall was analysed for amino acids using twodimensional TLC and then HPLC (Shimadzu) as described previously (Schleifer \& Kandler, 1972; Groth et al., 1996). Strain $10 \mathrm{a}^{\mathrm{T}}$ contained peptidoglycan with alanine, glutamic acid, lysine and aspartic acid in a molar ratio of $1.83: 1.0: 0.69: 0.63$ as the diagnostic amino acids, in contrast to the type species of the genus Bacillus, Bacillus subtilis, which was diagnosed with meso-diaminopimelic acid in the cell-wall peptidoglycan (Schleifer \& Kandler, 1972). During this study, B. fusiformis DSM $2898^{\mathrm{T}}$ produced similar results in cell-wall peptidoglycan analysis, with lysine, alanine, glutamic acid and aspartic acid in a similar molar ratio to strain $10 \mathrm{a}^{\mathrm{T}}$. This represents peptidoglycan type $\mathrm{A} 4 \alpha$ (Lys-Asp) as described by Schleifer \& Kandler (1972). The close relative B. sphaericus was reported to contain L-Lys-DAsp in the peptidoglycan as the diagnostic amino acids by Stackebrandt et al. (1987). So far, peptidoglycan consisting of Lys-Asp has not been reported for any other endosporeforming species of Bacillus group 2 (Ash et al., 1991; Stackebrandt et al., 1987; Nakamura et al., 2002; Ranftl \& Kandler, 1970; Rheims et al., 1999; Claus \& Fritze, 1989), but the closely related species of Kurthia (Fig. 1) share this characteristic (Shaw \& Keddie, 1983).

For whole-cell fatty acid analysis, the cells were grown on TSA for $24 \mathrm{~h}$ at $28^{\circ} \mathrm{C}$ and the cellular fatty acid profile was determined using the GC-based Microbial Identification system (MIDI) according to the manufacturer's instructions. The cellular fatty acid profile for the novel strains consisted predominantly of iso- and anteiso-branched fatty acids (Table 3), which is similar to other members of the $B$. sphaericus-like group. A MIDI database search of profiles also supported the novel species status of the strains, as there was no match to any known species. Polar lipids were extracted and purified from $100 \mathrm{mg}$ dried cells of strain $10 \mathrm{a}^{\mathrm{T}}$, B. fusiformis DSM $2898^{\mathrm{T}}$ and B. sphaericus IAM $13420^{\mathrm{T}}$ by the procedure of Minnikin et al. (1984) and examined by two-dimensional TLC, using Kieselgel $60 \mathrm{~F}_{254}$ plates (Merck), as described by Kudo (2001). Strain $10 \mathrm{a}^{\mathrm{T}}$ shared a similar polar lipid profile with B. fusiformis DSM $2898^{\mathrm{T}}$ and B. sphaericus IAM $13420^{\mathrm{T}}$, which consisted predominantly of diphosphatidylglycerol, phosphatidylglycerol and ninhydrin-positive phosphoglycolipid (Supplementary Fig. S4). The chemotaxonomic data showed some significant differences when compared with members of closely related genera, particularly the type species of the genus Bacillus in terms of polar lipid analysis (Kämpfer et al., 2006).

On the basis of chemical composition and genotypic and phenotypic data presented in this paper, the isolated strains $10 \mathrm{a}^{\mathrm{T}}, 11 \mathrm{c}$ and $12 \mathrm{~B}$ are assigned to a novel species in a new genus, Lysinibacillus boronitolerans gen. nov., sp. nov., with the type strain $10 \mathrm{a}^{\mathrm{T}}$. The chemotaxonomic data and phylogenetic analyses (Fig. 1) also demonstrated that Bacillus fusiformis and Bacillus sphaericus should be transferred to the genus Lysinibacillus as Lysinibacillus fusiformis comb. nov. and Lysinibacillus sphaericus comb. nov. Data on peptidoglycan composition and polar lipids of the nextclosest phylogenetically related species, $B$. massiliensis and B. odysseyi, are not available; therefore, inclusion of these species in the genus Lysinibacillus is not recognized here. $B$. silvestris contains peptidoglycans with L-lysine and D-glutamate and its major polar lipids are phosphatidylglycerol, diphosphatidylglycerol and phosphatidylethanolamine 
Table 1. Characteristics that differentiate the novel strains (Lysinibacillus boronitolerans) from closely related type strains

Strains: 1, strains $10 \mathrm{a}^{\mathrm{T}}, 11 \mathrm{c}$ and 12B (Lysinibacillus boronitolerans gen. nov., sp. nov.) (data from this study); 2, B. fusiformis DSM 2898 ${ }^{\mathrm{T}}$ (Lysinibacillus fusiformis) (data from Priest et al., 1988); 3, B. sphaericus IAM $13420^{\mathrm{T}}$ (Lysinibacillus sphaericus) (Claus \& Berkeley, 1986); 4, B. odysseyi ATCC PTA-4993 ${ }^{\mathrm{T}}$ (La Duc et al., 2004); 5, B. massiliensis CIP 108446 ${ }^{\mathrm{T}}$ (Glazunova et al., 2006); 6, B. silvestris DSM 12223 (Rheims et al., 1999); 7, B. pycnus JCM $11075^{\mathrm{T}}$ (Nakamura et al., 2002); 8, B. neidei JCM 11075 ${ }^{\mathrm{T}}$ (Nakamura et al., 2002); 9, B. arenosi LMG $22166^{\mathrm{T}}$ (Heyrman et al., 2005); 10, B. arvi LMG $22165^{\mathrm{T}}$ (Heyrman et al., 2005). All type strains produced positive results for motility, growth without $\mathrm{NaCl}$ and catalase activity and negative results for $\mathrm{H}_{2} \mathrm{~S}$ production and indole production. ND, No data available; v, variable results; +, positive; w, weakly positive; - , negative.

\begin{tabular}{|c|c|c|c|c|c|c|c|c|c|c|}
\hline Characteristic & 1 & 2 & 3 & 4 & 5 & 6 & 7 & 8 & 9 & 10 \\
\hline Cell size $(\mu \mathrm{m})$ (length $\times$ diameter $)$ & $\begin{array}{c}3.0-5.0 \times \\
0.8-1.5\end{array}$ & ND & $\begin{array}{c}1.5-5.0 \times \\
0.6-1.0\end{array}$ & $\begin{array}{c}4.0-5.0 \times \\
1.0\end{array}$ & $\begin{array}{c}1.5-4.0 \times \\
0.3-0.5\end{array}$ & $\begin{array}{c}0.9-2.0 \times \\
0.5-0.7\end{array}$ & $\begin{array}{r}3.0-5.0 \times \\
1.0-1.5\end{array}$ & $\begin{array}{c}3.0-5.0 \times \\
1.0\end{array}$ & $\begin{array}{c}3.0-8.0 \times \\
0.8-1.0\end{array}$ & $\begin{array}{c}3.0-8.0 \times \\
0.8-1.0\end{array}$ \\
\hline Spore shape and position* ${ }^{*}$ & $\mathrm{R} / \mathrm{O}, \mathrm{T}, \mathrm{B}$ & $\mathrm{R}, \mathrm{C} / \mathrm{T}, \mathrm{B}$ & $\mathrm{R}, \mathrm{T}, \mathrm{B}$ & $\mathrm{R}, \mathrm{T}, \mathrm{B}$ & ND & $\mathrm{R}, \mathrm{T}, \mathrm{B}$ & $\mathrm{R}, \mathrm{B}$ & $\mathrm{R}, \mathrm{B}$ & $\mathrm{R}, \mathrm{T}, \mathrm{B}$ & $\mathrm{R}, \mathrm{T}, \mathrm{B}$ \\
\hline pH range (optimum) & $\begin{array}{c}5.5-9.5 \\
(7.0-8.0)\end{array}$ & $6.0-9.5$ & $6.0-9.5$ & $\begin{array}{c}6.0-10.0 \\
(7.0)\end{array}$ & $\mathrm{ND}$ & $\mathrm{ND}$ & $\mathrm{ND}$ & $\mathrm{ND}$ & $(7.0-9.0)$ & $(7.0-9.0)$ \\
\hline Growth in $7 \%(\mathrm{w} / \mathrm{v}) \mathrm{NaCl}$ & - & + & - & - & - & - & - & ND & - & - \\
\hline Nitrate reduction & - & - & - & - & $\mathrm{ND}$ & - & - & - & + & - \\
\hline Oxidase & + & + & + & - & + & - & $\mathrm{ND}$ & $\mathrm{ND}$ & - & - \\
\hline L-Arginine dihydrolase & + & $\mathrm{ND}$ & $\mathrm{ND}$ & - & + & - & $\mathrm{ND}$ & $\mathrm{ND}$ & - & - \\
\hline L-Lysine and L-ornithine decarboxylase & - & $\mathrm{ND}$ & ND & + & + & ND & $\mathrm{ND}$ & $\mathrm{ND}$ & - & - \\
\hline Tryptophan deaminase & + & $\mathrm{ND}$ & $-{ }^{a_{\ddagger}}$ & $-{ }^{a}$ & + & $-{ }^{a}$ & $-{ }^{a}$ & $-{ }^{a}$ & $\mathrm{ND}$ & $\mathrm{ND}$ \\
\hline \multicolumn{11}{|l|}{ Hydrolysis of: } \\
\hline Urea & + & + & - & - & + & $+^{a}$ & $-{ }^{a}$ & $+^{a}$ & - & + \\
\hline N-Acetyl-D-glucosamine & + & $\mathrm{ND}$ & $\mathrm{ND}$ & - & ND & - & $\mathrm{ND}$ & $\mathrm{ND}$ & - & $\mathrm{w}$ \\
\hline \multicolumn{11}{|l|}{ Resistance to $\left(\mu \mathrm{g} \mathrm{ml}^{-1}\right)$ : } \\
\hline Chloramphenicol (8) & - & + & $+\mathrm{w}$ & $\mathrm{ND}$ & - & $\mathrm{ND}$ & - & - & $\mathrm{ND}$ & ND \\
\hline Erythromycin (1) & - & + & $+\mathrm{w}$ & $\mathrm{ND}$ & $\mathrm{ND}$ & $\mathrm{ND}$ & - & - & $\mathrm{ND}$ & $\mathrm{ND}$ \\
\hline Rifampicin (0.25) & - & - & $+\mathrm{w}$ & $\mathrm{ND}$ & - & ND & ND & ND & $\mathrm{ND}$ & $\mathrm{ND}$ \\
\hline Streptomycin (8) & - & $+\mathrm{w}$ & + & $\mathrm{ND}$ & - & $\mathrm{ND}$ & - & - & $\mathrm{ND}$ & $\mathrm{ND}$ \\
\hline Tetracycline (2) & - & - & + & $\mathrm{ND}$ & - & $\mathrm{ND}$ & - & - & $\mathrm{ND}$ & ND \\
\hline \multicolumn{11}{|l|}{ Oxidation of: } \\
\hline Pyruvate & + & $+^{b}$ & $++^{b}$ & + & + & $+^{a}$ & + & - & $\mathrm{ND}$ & $\mathrm{ND}$ \\
\hline$\alpha$-Hydroxybutyrate & + & $--^{b}$ & $-b$ & + & - & $--^{a}$ & $--^{a}$ & $\mathrm{ND}$ & $\mathrm{ND}$ & $\mathrm{ND}$ \\
\hline$\beta$-Hydroxybutyrate & - & $-{ }^{b}$ & $-{ }^{b}$ & + & - & $+{ }^{a}$ & + & - & $\mathrm{ND}$ & $\mathrm{ND}$ \\
\hline
\end{tabular}




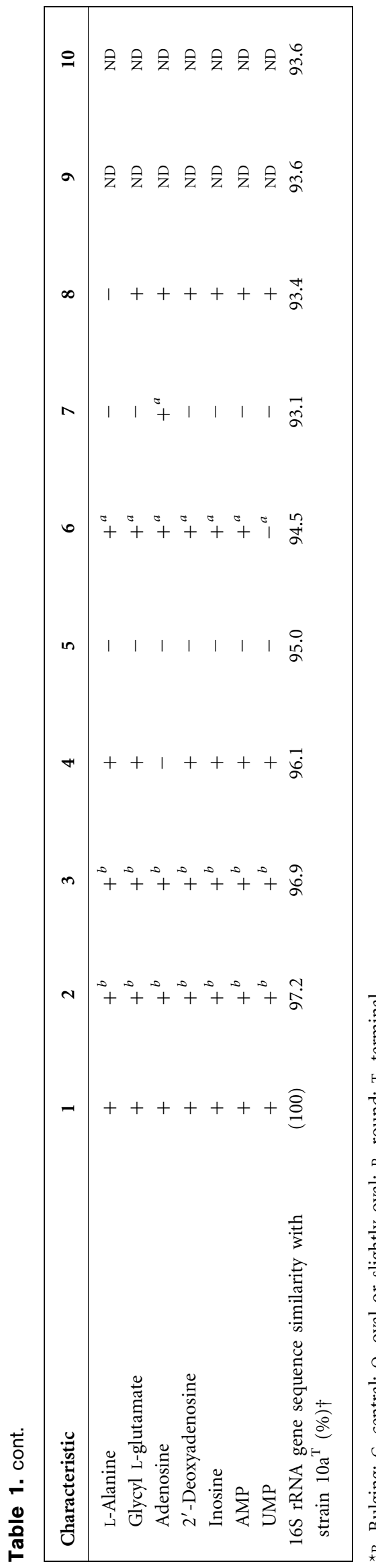

together with minor amounts of phosphatidylserine and an unknown phospholipid. This chemical composition differentiates $B$. silvestris from members of the novel genus Lysinibacillus.

\section{Description of Lysinibacillus gen. nov}

Lysinibacillus (Ly.si'ni.ba.cil'lus. N.L. n. lysinum lysine; L. masc. n. bacillus a small staff or rod; N.L. masc. n. Lysinibacillus lysine bacillus, referring to the presence of the Lys-Asp type of peptidoglycan in the cell wall).

Motile, rod-shaped cells that produce ellipsoidal or spherical endospores which lie terminally in a swollen sporangium. Oxidase and catalase tests are positive, whereas the production of indole and $\mathrm{H}_{2} \mathrm{~S}$, nitrate reduction and $\beta$ galactosidase (ONPG) tests are negative. Major cellular fatty acid is iso- $\mathrm{C}_{15: 0}$. Cell-wall peptidoglycan contains lysine and aspartic acid as the diagnostic amino acids, representing the cell wall peptidoglycan type A4 $\alpha$ (Lys-Asp). The dominant respiratory lipoquinone system is MK-7. Major polar lipids are diphosphatidylglycerol, phosphatidylglycerol and ninhydrin-positive phosphoglycolipid. The $\mathrm{G}+\mathrm{C}$ content is $35-38 \mathrm{~mol} \%$. The type species is Lysinibacillus boronitolerans.

\section{Description of Lysinibacillus boronitolerans sp. nov.}

Lysinibacillus boronitolerans (bo.ro'ni.to'le.rans. N.L. n. boron -onis boron; L. part. adj. tolerans tolerating; N.L. part. adj. boronitolerans boron-tolerating).

In addition to the characteristics described for the genus, the species has the following features. Cells are 3.0-5.0 $\mu \mathrm{m}$ long and $0.8-1.5 \mu \mathrm{m}$ in diameter. Colonies are circular with entire margins, flat/umbonate elevation, opaque and butyrous in texture and $2-3 \mathrm{~mm}$ in diameter after 2 days on NA (pH 7.0) plates at $37^{\circ} \mathrm{C}$. Temperature for growth is $16-$ $45^{\circ} \mathrm{C}$, with optimum growth at $37^{\circ} \mathrm{C}$; there is no growth at $\geqslant 50^{\circ} \mathrm{C}$ and little growth at $16^{\circ} \mathrm{C}$ after several days. Growth is observed at $\mathrm{pH} 5.5-9.5$, with optimum growth at $\mathrm{pH} 7.0-$ 8.0 (most rapid initial growth at $\mathrm{pH}$ 7.5) but no growth at pH 5.0. Tolerates $0-100 \mathrm{mM}$ boron in agar media, with optimum growth in the absence of boron and some growth at $150 \mathrm{mM}$ boron after 2 days. $\mathrm{NaCl}$ is tolerated up to $5 \%$ $(\mathrm{w} / \mathrm{v})$, indicating that it is moderately halotolerant. Growth is seen on marine agar 2216, TSA and NA with or without addition of boron or $\mathrm{NaCl}$. Acid is produced from $\mathrm{N}$-acetylD-glucosamine, D-xylose (weak) and aesculin (weak) (API $50 \mathrm{CH}$ ); acid is not produced from carbohydrates (API 20E). Positive for Voges-Proskauer test, urease, L-arginine dihydrolase, tryptophan deaminase and citrate utilization and negative for hydrolysis of gelatin and L-lysine and Lornithine decarboxylases. Oxidizes the following substrates: D-alanine, glycogen, D-ribose, D-tagatose, inosine, L-alanine, L-alanyl glycine, $\beta$-cyclodextrin, 2 -aminoethanol, L-histidine, L-leucine, L-ornithine, L-proline, L-threonine, acetic acid, glycyl L-glutamic acid, L-lactic acid, L-malic acid, L-glutamic acid, 2'-deoxyadenosine, L-serine, pyruvic acid, 


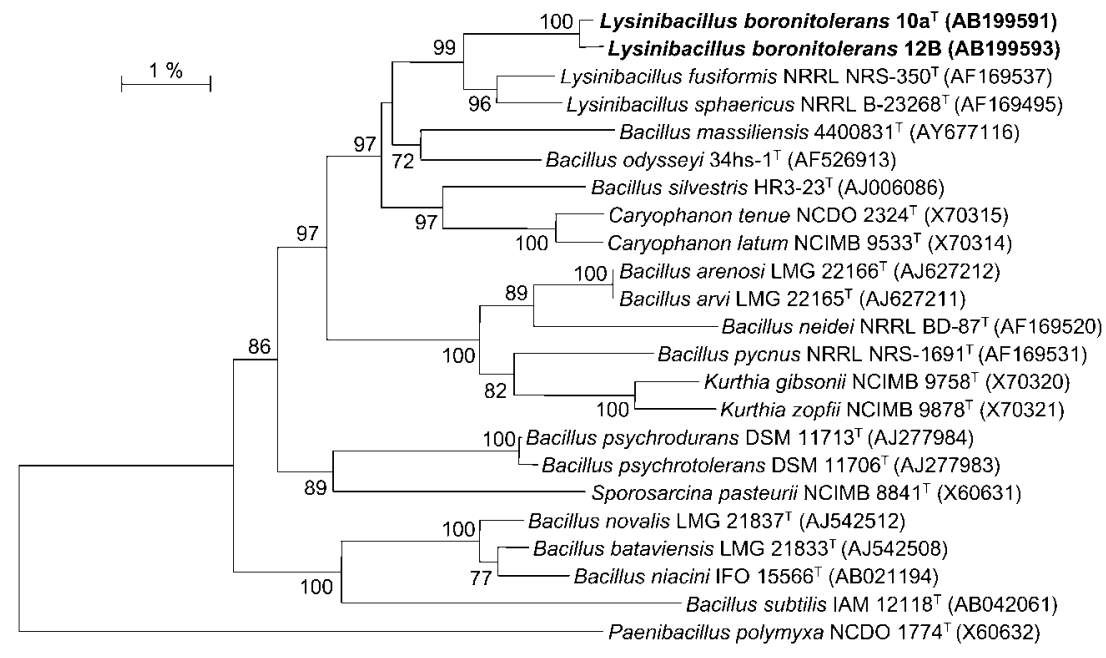

Fig. 1. Phylogenetic tree showing the interrelationships among strains $10 \mathrm{a}^{\top}$ and $12 \mathrm{~B}$ (Lysinibacillus boronitolerans gen. nov., sp. nov.) and their close relatives inferred from $16 \mathrm{~S}$ rRNA gene sequences. Data with gaps were removed using BioEdit software during alignment for construction of the rooted tree using the neighbour-joining method contained in the PHYLIP package (Felsenstein, 2005) and the tree was plotted with NJPlot, based on a comparison of approximately 1294 nucleotides. Bootstrap values, expressed as percentages of 1000 replications, are given at branching points. The sequence of Paenibacillus polymyxa NCDO $1774^{\top}$ was used as the outgroup. Bar, $1 \%$ sequence divergence.

methyl pyruvic acid, TMP, monomethyl succinate, UMP, propionic acid, alaninamide, adenosine, AMP, lactamide, L-asparagine, thymidine, uridine, $\alpha$-hydroxybutyric acid, $\alpha$-ketovaleric acid, bromosuccinic acid, cis-aconitic acid, citric acid, DL-lactic acid, formic acid, gluconic acid, glycyl L-aspartic acid, i-erythritol, L-aspartic acid and $\alpha$-ketobutyric acid. Major cellular fatty acids are iso- $\mathrm{C}_{15: 0}(32 \%)$, anteiso- $\mathrm{C}_{15: 0}(21 \%)$, iso- $\mathrm{C}_{16: 0}(11 \%)$, anteiso- $\mathrm{C}_{17: 0}$ $(11 \%), \mathrm{C}_{16: 1} \omega 7 c$ alcohol $(8 \%)$, iso- $\mathrm{C}_{17: 0}(6 \%)$ and iso$\mathrm{C}_{14: 0}(2 \%)$. Cell-wall peptidoglycan contains lysine, alanine, glutamic acid and aspartic acid as the diagnostic amino acids. In addition to the polar lipids given in the genus description, it also contains phosphatidylethanolamine. Strong enzyme activity is observed for $\alpha$-chymotrypsin and esterase (C8), whereas weak activity is observed for alkaline phosphatase, esterase lipase (C8), leucine arylamidase, acid phosphatase, valine arylamidase and naphthol-AS-BI-phosphohydrolase (API ZYM). The type strain is resistant to linomycin, colistin, sulfamethizol, oxolinic acid, fusidic acid and metronidazol (ATB-VET).
The $\mathrm{G}+\mathrm{C}$ content of the type strain is $36.5 \mathrm{~mol} \%$ (determined by HPLC).

Strain $10 \mathrm{a}^{\mathrm{T}}\left(=\mathrm{DSM} 17140^{\mathrm{T}}=\right.$ IAM $15262^{\mathrm{T}}=$ ATCC BAA$1146^{\mathrm{T}}$ ) is the type strain, isolated from soil collected in the experimental area of the University of Tokyo (Yayoi campus), Japan.

\section{Description of Lysinibacillus fusiformis comb. nov.}

Lysinibacillus fusiformis (fu.si.for'mis. L. n. fusus spindle; L. n. forma shape, form; N.L. adj. fusiformis spindle-shaped).

Basonym: Bacillus fusiformis (ex Meyer and Gottheil 1901) Priest et al. 1988.

The description of the species as given by Priest et al. (1988) is unchanged. Cell-wall peptidoglycan contains lysine, alanine, glutamic acid and aspartic acid in the molar ratio of $1.81: 1.0: 0.69: 0.64$ as diagnostic amino acids. Cellular

Table 2. Characteristics that differentiate the genus Lysinibacillus gen. nov. from closely related genera

Data for reference genera were taken from Claus et al. (1992) (Caryophanon and Sporosarcina), Keddie \& Jones (1992) (Kurthia) and Claus \& Berkeley (1986) (Bacillus) unless indicated. +, Positive; -, negative; NA, data not available; $m$-DAP, meso-diaminopimelic acid.

\begin{tabular}{|c|c|c|c|c|c|}
\hline Characteristic & Lysinibacillus & Caryophanon & Kurthia & Sporosarcina & Bacillus \\
\hline Endospore formation & + & - & - & + & + \\
\hline Rod-shaped cells & + & Trichome rods & + & - & + \\
\hline Oxidase & + & - & NA & + & + \\
\hline Nitrate reduced to nitrite & - & - & - & + & + \\
\hline Cell-wall type & Lys-Asp & L-Lys-D-Glu ${ }^{a_{\star}}$ & L-Lys-D-Asp & L-Lys-Gly-D-Glu ${ }^{a}$ & $m-\mathrm{DAP}^{b}$ \\
\hline Menaquinone system & MK-7 & MK-6 & MK-7 & MK-7 & MK-7 \\
\hline Major fatty acid & iso- $\mathrm{C}_{15: 0}$ & NA & NA & anteiso- $\mathrm{C}_{15: 0}{ }^{c}$ & anteiso- $\mathrm{C}_{15: 0}{ }^{d}$ \\
\hline $\mathrm{G}+\mathrm{C}$ content $(\mathrm{mol} \%)$ & $35-38 \dagger$ & $44-46$ & $36-38$ & $40-42$ & $32-69$ \\
\hline
\end{tabular}

${ }^{\star}$ Data from other studies as follows: $a$, Stackebrandt et al. (1987); b, Schleifer \& Kandler (1972); c, Yoon et al. (2001); d, Kämpfer et al. (2006). $\dagger$ Data for G + C content of B. fusiformis from Fahmy et al. (1985) and B. sphaericus from Priest et al. (1988). 
Table 3. Cellular fatty acid compositions of the novel strains and closely related taxa

Strains: 1, strains $10 \mathrm{a}^{\mathrm{T}}, 11 \mathrm{c}$ and $12 \mathrm{~B}$ (L. boronitolerans) (results are based on two replicates for each strain); 2, B. fusiformis (L. fusiformis) (data for three strains); 3, B. sphaericus (L. sphaericus) (three strains); 4, B. arenosi (three strains; data from Heyrman et al., 2005); 5 , B. arvi (two strains; Heyrman et al., 2005); 6, B. massiliensis CIP 108446 ${ }^{\mathrm{T}}$ (Glazunova et al., 2006); 7, B. silvestris DSM $12223^{\mathrm{T}}$ (Rheims et al., 1999). -, Not detected/not reported.

\begin{tabular}{|c|c|c|c|c|c|c|c|}
\hline Fatty acid & 1 & 2 & 3 & 4 & 5 & 6 & 7 \\
\hline $\mathrm{C}_{15: 0}$ & $0.5 \pm 0.07$ & $1.1 \pm 0.1$ & - & $3.7 \pm 0.9$ & $2.2 \pm 0.5$ & 3.2 & - \\
\hline $\mathrm{C}_{17: 0}$ & - & - & - & - & - & - & 0.9 \\
\hline iso- $\mathrm{C}_{14: 0}$ & $1.7 \pm 0.48$ & $2.8 \pm 0.1$ & $2.3 \pm 0.3$ & $5.2 \pm 1.7$ & $12.8 \pm 0.3$ & 3.1 & 2.9 \\
\hline iso- $\mathrm{C}_{15: 1}$ at 5 & - & - & $0.5 \pm 0.1$ & - & - & - & - \\
\hline iso- $\mathrm{C}_{16: 0}$ & $11.2 \pm 2.61$ & $15.7 \pm 0.3$ & $8.2 \pm 0.7$ & $5.4 \pm 2.1$ & $15.1 \pm 1.2$ & 13.5 & 6.2 \\
\hline iso- $\mathrm{C}_{16: 1}$ & - & - & - & - & - & - & 18.7 \\
\hline iso- $\mathrm{C}_{17: 0}$ & $5.5 \pm 1.01$ & $4.4 \pm 0.2$ & $7.0 \pm 1.8$ & $3.4 \pm 0.5$ & $1.9 \pm 0.2$ & 3.7 & 5.1 \\
\hline anteiso- $\mathrm{C}_{17: 0}$ & $11.1 \pm 3.22$ & $9.2 \pm 0.4$ & $1.7 \pm 0.4$ & $3.1 \pm 0.1$ & $5.0 \pm 0.4$ & 5.6 & 3.0 \\
\hline $\mathrm{C}_{18: 1} \omega 9 c$ & - & - & - & - & - & 0.7 & - \\
\hline Summed feature $4 \dagger$ & $2.8 \pm 0.66$ & $2.2 \pm 0.03$ & $2.2 \pm 0.10$ & $2.7 \pm 0.2$ & $2.4 \pm 0.1$ & - & - \\
\hline
\end{tabular}

${ }^{*}$ Rheims et al. (1999) designated these fatty acids as iso- $\mathrm{C}_{17: 1}$ and $\mathrm{C}_{16: 1}$, respectively, without providing information about the position of double bond and the type of isomer (cis/trans).

$\dagger$ Summed feature 4 comprises iso- $\mathrm{C}_{17: 1} \mathrm{I}$ and/or anteiso- $\mathrm{C}_{17: 1} \mathrm{~B}$.

fatty acid profile is listed in Table 3. Major polar lipids are diphosphatidylglycerol, phosphatidylglycerol and ninhydrinpositive phosphoglycolipid. The type strain is DSM $2898^{\mathrm{T}}$ $\left(=\mathrm{JCM} 12229^{\mathrm{T}}=\operatorname{LMG} 9816^{\mathrm{T}}=\right.$ ATCC $\left.7055^{\mathrm{T}}\right)$.

\section{Description of Lysinibacillus sphaericus comb. nov.}

Lysinibacillus sphaericus (sphae' ri.cus. L. masc. adj. sphaericus spherical).

Basonym: Bacillus sphaericus Meyer and Neide 1904.

In addition to the characteristics summarized by Claus \& Berkeley (1986), the cellular fatty acid composition is added to the description of the species (Table 3). Major polar lipids are diphosphatidylglycerol, phosphatidylglycerol, ninhydrinpositive phosphoglycolipid and an unknown polar lipid. The type strain is DSM $28^{\mathrm{T}}$ ( = LMG $7134^{\mathrm{T}}=\mathrm{JCM} 2502^{\mathrm{T}}=$ ATCC $14577^{\mathrm{T}}=\mathrm{CCM} 2120^{\mathrm{T}}=\mathrm{NCIMB} 9370^{\mathrm{T}}=$ NCTC $\left.10338^{\mathrm{T}}\right)$.

\section{Acknowledgements}

We thank Dr A. Nozawa for technical guidance and suggestions, $\mathrm{Mr}$ X. Tian for help with the menaquinone analysis, Dr N. Bughio for providing valuable comments on the manuscript and the Ministry of Education, Culture, Sports, Science, and Technology of Japan for providing financial assistance to the first author.

\section{References}

Ahmed, I., Yokota, A. \& Fujiwara, T. (2007a). A novel highly boron tolerant bacterium, Bacillus boroniphilus sp. nov., isolated from soil, that requires boron for its growth. Extremophiles 11, 217-224.

Ahmed, I., Yokota, A. \& Fujiwara, T. (2007b). Gracilibacillus boraciitolerans sp. nov., a highly boron-tolerant and moderately halotolerant bacterium isolated from soil. Int J Syst Evol Microbiol 57, 796-802.

Ahmed, I., Yokota, A. \& Fujiwara, T. (2007c). Chimaereicella boritolerans sp. nov., a boron-tolerant and alkaliphilic bacterium of the family Flavobacteriaceae isolated from soil. Int J Syst Evol Microbiol 57, 986-992.

Ash, C., Farrow, J. A. E., Wallbanks, S. \& Collins, M. D. (1991). Phylogenetic heterogeneity of the genus Bacillus revealed by comparative analysis of small-subunit-ribosomal RNA sequences. Lett Appl Microbiol 13, 202-206.

Ash, C., Priest, F. G. \& Collins, M. D. (1993). Molecular identification of rRNA group 3 bacilli (Ash, Farrow, Wallbanks and Collins) using a PCR probe test. Antonie van Leeuwenhoek 64, 253-260.

Chen, X., Schauder, S., Potier, N., Dorsselaer, A. V., Pelczer, I., Bassler, B. L. \& Hughson, F. M. (2002). Structural identification of a bacterial quorum-sensing signal containing boron. Nature 415, 545-549.

Claus, D. \& Berkeley, R. C. W. (1986). Genus Bacillus Cohn 1872, $174^{\mathrm{AL}}$. In Bergey's Manual of Systematic Bacteriology, vol. 2, pp. 1105-1139. Edited by P. H. A. Sneath, N. S. Mair, M. E. Sharpe \& J. G. Holt. Baltimore: Williams \& Wilkins. 
Claus, D. \& Fritze, D. (1989). Taxonomy of Bacillus. In Bacillus (Biotechnology Handbooks vol. 2), pp. 5-26. Edited by C. R. Harwood. New York: Plenum.

Claus, D., Fritze, D. \& Kocur, M. (1992). Genera related to the genus Bacillus - Sporolactobacillus, Sporosarcina, Planococcus, Filibacter and Caryophanon. In The Prokaryotes: a Handbook on the Biology of Bacteria: Ecophysiology, Isolation, Identification, Applications, 2nd edn, vol. 2, pp. 1769-1791. Edited by A. Balows, H. G. Trüper, M. Dworkin, W. Harder \& K. H. Schleifer. New York: Springer.

Clausen, V., Jones, J. G. \& Stackebrandt, E. (1985). 16S ribosomal RNA analysis of Filibacter limicola indicates a close relationship to the genus Bacillus. J Gen Microbiol 131, 2659-2663.

Cochran, D. G. (1995). Toxic effects of boric acid on the German cockroach. Experientia 51, 561-563.

Ezaki, T., Hashimoto, Y. \& Yabuuchi, E. (1989). Fluorometric deoxyribonucleic acid-deoxyribonucleic acid hybridization in microdilution wells as an alternative to membrane filter hybridization in which radioisotopes are used to determine genetic relatedness among bacterial strains. Int J Syst Bacteriol 39, 224-229.

Fahmy, F., Flossdorf, J. \& Claus, D. (1985). The DNA base composition of the type strains of the genus Bacillus. Syst Appl Microbiol 6, 60-65.

Farrow, J. A. E., Wallbanks, S. \& Collins, M. D. (1994). Phylogenetic interrelationships of round-spore-forming bacilli containing cell walls based on lysine and the non-spore-forming genera Caryophanon, Exiguobacterium, Kurthia, and Planococcus. Int J Syst Bacteriol 44, $74-82$.

Felsenstein, J. (2005). PHYLIP (Phylogeny Inference Package) version 3.6. Distributed by the author. Department of Genome Sciences, University of Washington, Seattle, USA.

Glazunova, O. O., Raoult, D. \& Roux, V. (2006). Bacillus massiliensis sp. nov., isolated from cerebrospinal fluid. Int J Syst Evol Microbiol 56, 1485-1488.

Groth, I., Schumann, P., Weiss, N., Martin, K. \& Rainey, F. A. (1996). Agrococcus jenensis gen. nov., sp. nov., a new genus of actinomycetes with diaminobutyric acid in the cell wall. Int J Syst Bacteriol 46, 234-239.

Hall, T. A. (1999). BioEdit: a user-friendly biological sequence alignment editor and analysis program for Windows 95/98/NT. Nucleic Acids Symp Ser 41, 95-98.

Heyndrickx, M., Lebbe, L., Kersters, K., De Vos, P., Forsyth, G. \& Logan, N. A. (1998). Virgibacillus: a new genus to accommodate Bacillus pantothenticus (Proom and Knight 1950). Emended description of Virgibacillus pantothenticus. Int J Syst Bacteriol 48, 99-106.

Heyrman, J., Rodríguez-Díaz, M., Devos, J., Felske, A., Logan, N. A. \& De Vos, P. (2005). Bacillus arenosi sp. nov., Bacillus arvi sp. nov. and Bacillus humi sp. nov., isolated from soil. Int J Syst Evol Microbiol 55, 111-117.

Kämpfer, P., Rosselló-Mora, R., Falsen, E., Busse, H.-J. \& Tindall, B. J. (2006). Cohnella thermotolerans gen. nov., sp. nov., and classification of 'Paenibacillus hongkongensis' as Cohnella hongkongensis sp. nov. Int J Syst Evol Microbiol 56, 781-786.

Katsivela, E., Bonse, D., Krüger, A., Strömpl, C., Livingston, A. \& Ittich, R.-M. (1999). An extractive membrane biofilm reactor for degradation of 1,3-dichloropropene in industrial wastewater. Appl Microbiol Biotechnol 52, 853-862.

Keddie, R. M. \& Jones, D. (1992). The genus Kurthia. In The Prokaryotes: a Handbook on the Biology of Bacteria: Ecophysiology, Isolation, Identification, Applications, 2nd edn, vol. 2, pp. 1654-1662. Edited by A. Balows, H. G. Trüper, M. Dworkin, W. Harder \& K. H. Schleifer. New York: Springer.
Keddie, R. M. \& Shaw, S. (1986). Genus Kurthia. In Bergey's Manual of Systematic Bacteriology, vol. 2, pp. 1255-1258. Edited by P. H. A. Sneath, N. Mair, M. E. Sharpe \& J. G. Holt. Baltimore: Williams \& Wilkins.

Kimura, M. (1980). A simple method for estimating evolutionary rates of base substitutions through comparative studies of nucleotide sequences. J Mol Evol 16, 111-120.

Kudo, T. (2001). Phospholipids. In Identification Manual of Bacteria: Molecular Genetics and Molecular Biological Methods, pp. 135-144. Edited by K. Suzuki, A. Hiraishi \& A. Yokota. Tokyo: Springer.

La Duc, M. T., Satomi, M. \& Venkateswaran, K. (2004). Bacillus odysseyi sp. nov., a round-spore-forming bacillus isolated from the Mars Odyssey spacecraft. Int J Syst Evol Microbiol 54, 195-201.

Minnikin, D. E., O'Donnell, A. G., Goodfellow, M., Alderson, G., Athalye, M., Schaal, A. \& Parlett, J. H. (1984). An integrated procedure for the extraction of bacterial isoprenoid quinones and polar lipids. J Microbiol Methods 2, 233-241.

Nakamura, L. K., Shida, O., Takagi, H. \& Komagata, K. (2002). Bacillus pycnus sp. nov. and Bacillus neidei sp. nov., round-spored bacteria from soil. Int J Syst Evol Microbiol 52, 501-505.

Pechman, K. J., Lewis, B. J. \& Woese, C. R. (1976). Phylogenetic status of Sporosarcina ureae. Int J Syst Bacteriol 26, 305-310.

Priest, F. G., Goodfellow, M. \& Todd, C. (1988). A numerical classification of the genus Bacillus. J Gen Microbiol 134, 1847-1882.

Ranftl, H. \& Kandler, O. (1970). D-Aspartyl-L-alanin als Interpeptidbrücke im Murein von Bacillus pasteurii Migula. $Z$ Naturforsch [C] 28, 4-8 (in German).

Rheims, H., Frühling, A., Schumann, P., Rohde, M. \& Stackebrandt, E. (1999). Bacillus silvestris sp. nov., a new member of the genus Bacillus that contains lysine in its cell wall. Int J Syst Bacteriol 49, 795-802.

Rowe, R. I. \& Eckhert, C. D. (1999). Boron is required for zebrafish embryogenesis. J Exp Biol 202, 1649-1654.

Rowe, R. I., Bouzan, C., Nabili, S. \& Eckhert, C. D. (1998). The response of trout and zebrafish embryos to low and high boron concentrations is U-shaped. Biol Trace Elem Res 66, 261-270.

Saitou, N. \& Nei, M. (1987). The neighbor-joining method: a new method for reconstructing phylogenetic trees. Mol Biol Evol 4, 406-425.

Schleifer, K. H. \& Kandler, O. (1972). Peptidoglycan types of bacterial cell walls and their taxonomic implications. Bacteriol Rev 36, 407-477.

Shaw, S. \& Keddie, R. M. (1983). A numerical taxonomic study of the genus Kurthia with a revised description of Kurthia zopfii and a description of Kurthia gibsonii sp. nov. Syst Appl Microbiol 4, 253-276.

Shida, O., Takagi, H., Kadowaki, K. \& Komagata, K. (1996). Proposal for two new genera, Brevibacillus gen. nov. and Aneurinibacillus gen. nov. Int J Syst Bacteriol 46, 939-946.

Stackebrandt, E. \& Goebel, B. M. (1994). Taxonomic note: a place for DNA-DNA reassociation and 16S rRNA sequence analysis in the present species definition in bacteriology. Int J Syst Bacteriol 44, 846-849.

Stackebrandt, E., Ludwig, W., Weizenegger, M., Dorn, S., McGill, T. J., Fox, G. E., Woese, C. E., Schubert, W. \& Schleifer, K.-H. (1987). Comparative 16S rRNA oligonucleotide analyses and murein types of round-spore-forming bacilli and non-sporeforming relatives. J Gen Microbiol 133, 2523-2529.

Thompson, J. D., Gibson, T. J., Plewniak, F., Jeanmougin, F. \& Higgins, D. G. (1997). The CLUSTAL_X windows interface: flexible strategies for multiple sequence alignment aided by quality analysis tools. Nucleic Acids Res 25, 4876-4882. 
Wainø, M., Tindall, B. J., Schumann, P. \& Ingvorsen, K. (1999). Gracilibacillus gen. nov., with description of Gracilibacillus halotolerans gen. nov., sp. nov.; transfer of Bacillus dipsosauri to Gracilibacillus dipsosauri comb. nov., and Bacillus salexigens to the genus Salibacillus gen. nov., as Salibacillus salexigens comb. nov. Int J Syst Bacteriol 49, 821-831.

Warington, K. (1923). The effect of boric acid and borax on the broad bean and certain other plants. Ann Bot 37, 629-672.

Wisotzkey, J. D., Jurtshuk, P., Jr, Fox, G. E., Deinhard, G. \& Poralla, K. (1992). Comparative sequence analyses on the $16 \mathrm{~S}$ rRNA (rDNA) of Bacillus acidocaldarius, Bacillus acidoterrestris, and Bacillus cycloheptanicus and proposal for creation of a new genus, Alicyclobacillus gen. nov. Int J Syst Bacteriol 42, 263-269.
Xie, C. \& Yokota, A. (2003). Phylogenetic analysis of Lampropedia hyalina based on the 16S rRNA gene sequence. J Gen Appl Microbiol 49, 345-349.

Yoon, J.-H., Weiss, N., Lee, K.-C., Lee, I.-S., Kang, K. H. \& Park, Y.-H. (2001). Jeotgalibacillus alimentarius gen. nov., sp. nov., a novel bacterium isolated from jeotgal with L-lysine in the cell wall, and reclassification of Bacillus marinus Rüger 1983 as Marinibacillus marinus gen. nov., comb. nov. Int J Syst Evol Microbiol 51, 20872093.

Yoon, J. H., Kang, K. H. \& Park, Y. H. (2002). Lentibacillus salicampi gen. nov., sp. nov., a moderately halophilic bacterium isolated from a salt field in Korea. Int J Syst Evol Microbiol 52, 20432048. 